\title{
Manufacturing and Economic Growth in ECOWAS Countries: A Test of Kaldor's First Law
}

\author{
Yaya Keho \\ Ecole Nationale Supérieure de Statistique et d'Economie Appliquée (ENSEA), Abidjan, Côte d'Ivoire \\ Email: yayakeho@yahoo.fr
}

How to cite this paper: Keho, Y. (2018) Manufacturing and Economic Growth in ECOWAS Countries: A Test of Kaldor's First Law. Modern Economy, 9, 897-906. https://doi.org/10.4236/me.2018.95057

Received: February 22, 2018

Accepted: May 8, 2018

Published: May 11, 2018

Copyright (C) 2018 by author and Scientific Research Publishing Inc. This work is licensed under the Creative Commons Attribution International License (CC BY 4.0).

http://creativecommons.org/licenses/by/4.0/

\section{(c) (i) Open Access}

\begin{abstract}
Kaldor's first growth law posits that the growth rate of an economy is positively related to the growth rate of its manufacturing sector. Since the sixties, this relationship has been examined in a large number of studies using a wide variety of data sets and econometric methods. This paper examines the validity of this law for 11 ECOWAS member countries over the period 1970-2014 by employing an Autoregressive Distributed Lag bounds test approach to cointegration and Granger causality tests. The results show that manufacturing output growth causes positively economic growth and non-manufacturing output growth, thereby providing support for Kaldor's first growth law. The policy recommendation from the results of the study is that structural transformation in favour of industrial production activities would help to accelerate economic growth in ECOWAS countries.
\end{abstract}

\section{Keywords}

Kaldor's Law, Economic Growth, Manufacturing, ECOWAS

\section{Introduction}

The sources of economic growth have long been a subject of discussion among economists. In the 1960s, Nicolas Kald or put forward three laws advocating that the manufacturing industry sector is the main engine of economic growth. These laws were based on an econometric analysis of the output, productivity and employment growth rates of 12OECD countries over the 50's and 60's. According to the first law, the growth rate of an economy is positively related to the growth rate of its manufacturing or industrial sector. This positive relation can be explained by the effects of manufacturing on productivity levels in the whole economy. Such effects are related to the transfer of labor from low productivity sectors to the industrial sector and to the existence of economies of scale in 
manufacturing. The second law states that the labor productivity is positively related to the growth rate of manufacturing sector through increasing returns to scale due to learning by doing processes and efficiency changes. This relationship was firstly suggested by Verdoorn [1] and tested by Kaldor [2]. This second law is also known as Kaldor-Verdoorn law or only Verdoorn law. The third law establishes a positive relationship between productivity growth in the nonmanufacturing sector and the growth in manufacturing output. The growth of manufacturing sector increases productivity in nonmanufacturing sector by drawing surplus labor in these sectors and reducing disguised unemployment.

These three laws have been investigated in a large number of empirical studies employing different econometric methods [3]-[11]. Overall, these studies found a positive association between growth rate of industrial output and economic growth, confirming Kaldor's first law. The testing approach of the first law employed in most of these studies follows Kaldor's original model that consists in regressing real GDP growth rate on the growth rate of manufacturing or industrial output. If GDP and manufacturing output are cointegrated, this "old" approach is clearly misspecified and suffers from the bias of omitted variables. Another shortcoming of these studies is that they do not formally test the causality between manufacturing and economic growth. The validity of Kaldor's first law requires a causality running from manufacturing sector to economic growth. The positive correlation between the two variables is not simply because manufacturing output is a component of total GDP but in a fundamental causal sense related to the production characteristics of manufacturing activities [2] [12]. This paper examines the validity of Kaldor's first law for ECOWAS member countries, looking more closely at the issue of cointegration and causality between manufacturing growth and economic growth. The study intends to test the hypothesis whether the economic growth of ECOWAS countries is positively related to the growth of manufacturing industry in a fundamental sense.

The rest of the paper is organized as follows. Section 2 outlines the econometric methodology of the study. Section 3 describes the data used in the empirical analysis. Section 4 discusses the empirical results and Section 5 concludes the study and provides some policy recommendations.

\section{Econometric Methodology}

Kaldor's first law states that there is a close relation between the growth rate of manufacturing output and the growth rate of GDP. In most existing studies, this law has been tested using the following econometric model:

$$
\Delta \log y_{t}=\alpha_{1}+\beta_{1} \Delta \log \operatorname{man}_{t}+\mu_{1 t}
$$

where $\Delta \log y_{t}$ is the growth rate of real GDP, $\Delta \operatorname{logman} n_{t}$ is the growth rate of manufacturing output, and $\mu_{t}$ is a well-behaved error term.

The validity of Kaldor's first law requires that the coefficient $\beta_{1}$ is statistically significant and positive. However, a problem with Equation (1) is that manufacturing output is a component of GDP and hence there will be an obvious posi- 
tive relationship between the growth of manufacturing output and the growth of GDP. In order to avoid this simultaneity bias, we consider GDP net of manufacturing by subtracting manufacturing output from GDP. The analysis is then reduced to examining the relationship between manufacturing sector and nonmanufacturing sector. Evidence supporting Kaldor's first law is when the growth of non-manufacturing output responds positively to the growth of manufacturing. This is evaluated using the following equation:

$$
\Delta \log n \operatorname{man}_{t}=\alpha_{2}+\beta_{2} \Delta \log \operatorname{man}_{t}+\mu_{2 t}
$$

where $\Delta \operatorname{logman}{ }_{t}$ is the growth rate of manufacturing output and $\Delta \log n \operatorname{man}_{t}$ is the growth rate of non-manufacturing output.

Existing studies estimated Equation (1) and Equation (2) using standard econometric methods (OLS, fixed-effects, random-effects).

A major problem with these specifications is that they will be subject to omitted-variables bias if variables in levels (GDP and manufacturing output) are cointegrated [13]. To address this econometric problem, our empirical investigation will involve three steps. As an initial step, stationarity tests are performed for both variables. If variables are integrated of order one, we test for the presence of a long-run relationship among them using the Autoregressive Distributed Lag (ARDL) bounds test developed by Peasaran et al. [14]. This method is based on the following ARDL-ECM equation:

$\Delta \log y_{t}=\varphi_{0}+\varphi_{1} \log y_{t-1}+\varphi_{2} \log \operatorname{man}_{t-1}+\sum_{i=1}^{m} \gamma_{1 i} \Delta \log y_{t-i}+\sum_{i=0}^{n} \gamma_{2 i} \Delta \log \operatorname{man}_{t-i}+e_{t}$ (3) where $\Delta$ is the difference operator, $\phi_{1}$ and $\phi_{2}$ are the long-run multipliers, while $\gamma_{1 \mathrm{i}}$ and $\gamma_{2 \mathrm{i}}$ are the short-run dynamics of the variables. The presence of a long-run relationship is tested by restricting coefficients of lagged level variables equal to zero. That is, the null hypothesis of no long-run relationship is: $\varphi_{1}=\varphi_{2}=0$. This hypothesis is tested by the mean of an $F$-test. The asymptotic critical values are provided by Pesaran et al. [14]. The bounds testing procedure is sensitive to the selection of the lag structure $(m, n)$. In this study, the lag structure was selected using the Akaike Information Criterion (AIC) with maximum lag length on each variable set to five.

If the variables under study are cointegrated then Kaldor's first law will be tested using the following equations:

$$
\begin{gathered}
\Delta \log y_{t}=\alpha_{1}+\beta_{1} \Delta \log \operatorname{man}_{t}+\lambda_{1} e c m_{1 t-1}+\mu_{1 t} \\
\Delta \log n \operatorname{man}_{t}=\alpha_{2}+\beta_{2} \Delta \log \operatorname{man}_{t}+\lambda_{2} e c m_{2 t-1}+\mu_{2 t}
\end{gathered}
$$

where $e c m_{1 t-1}=\log y_{t-1}-\theta_{0}-\theta_{1} \log \operatorname{man}_{t-1}$ and $e c m_{2 t-1}=\log n \operatorname{man}_{t-1}-\gamma_{0}-\gamma_{1} \log \operatorname{man}_{t-1}$ are the lagged residuals of the long-run relationships between GDP and manufacturing output and between non-manufacturing output and manufacturing output, respectively.

Cointegration indicates only whether or not a long-run relationship exists between the variables. It does not indicate the direction of the causal relationship among them. Engle and Granger [13] argued that as long as variables are coin- 
tegrated, causality must exist at least in one direction. Following their methodology the direction of causality between manufacturing outputand GDP can be detected by estimating the following Error Correction Models:

$$
\begin{gathered}
\Delta \log y_{t}=\alpha_{1}+\sum_{i=1}^{p} \gamma_{1 i} \Delta \log y_{t-i}+\sum_{i=1}^{p} \varphi_{1 i} \Delta \log \operatorname{man}_{t-i}+\lambda_{1} e c m_{t-1}+e_{1 t} \\
\Delta \log \operatorname{man}_{t}=\alpha_{2}+\sum_{i=1}^{p} \gamma_{2 i} \Delta \log y_{t-i}+\sum_{i=1}^{p} \varphi_{2 i} \Delta \log \operatorname{man}_{t-i}+\lambda_{2} e c m_{t-1}+e_{2 t}
\end{gathered}
$$

The lag length $p$ is determined using the Akaike Information Criterion (AIC). The significance of the differenced explanatory variables indicates the short-run causality, whereas the significance of $e \mathrm{~cm}_{t-1}$ confirms the long-run causal relationship. For example, manufacturing output growth does not cause GDP growth in the short-run if $\varphi_{11}=\varphi_{12}=\ldots=\varphi_{1 \mathrm{p}}=0$. Similarly, GDP growth does not cause manufacturing output growth in the short-run if none of $\gamma_{2 \mathrm{i}}$ is statistically different from zero.

\section{Data Description}

The study uses annual time series data for 11 ECOWAS member countries over the period from 1970 to 2014. The countries under study include: Benin, Burkina Faso, Cote d'Ivoire, Gambia, Ghana, Mali, Niger, Nigeria, Senegal, Sierra Leonne, and Togo. The coverage of countries and time period are dictated by the availability of continuous data over the sample period. The variables under study are real GDP and real industrial valued added both in constant 2010 US dollar. They were sourced from the World Development Indicators of the World Bank. For Cote d'Ivoire, Ghana and Niger, industral output was computed on the basis of its share in GDP. All data were converted into natural logarithms so that they can be interpreted in growth terms after taking first difference. The descriptive statistics of the variables are reported in Panel A of Table 1. Looking at that Table we note that the average economic growth rate ranges from $2.25 \%$ in Niger to $5.08 \%$ in Mali. The standard deviation shows heterogeneity across countries. The correlation coefficient suggests a positive relationship between manufacturing output growth and GDP growth in all countries except Gambia. However, this finding does not prove that manufacturing output growth influences GDP growth. Is there any evidence of manufacturing-led growth or the reverse? Does any causality exist between manufacturing and GDP in the countries under study?

The statistics reported in Panel B of Table 1 show a low and limited variability of manufacturing output relative to GDP across countries. Nigeria is the only country with an average manufacturing output ratio exceeding 30 percent of GDP. Except Nigeria and Senegal, the share of agricultural sector is higher than that of manufacturing sector in the rest of ECOWAS countries. The size of the manufacturing sector in ECOWAS countries is relatively smaller compared to East Asian countries where it exceeds 50 per cent of GDP. Obviously, more 
Table 1. Descriptive statistics of the variables. Panel (a): GDP growth and manufacturing output growth; Panel (b): Manufacturing and agricultural output as share of GDP.

(a)

\begin{tabular}{cccccccccc}
\hline & \multicolumn{3}{c}{ GDP growth (\%) } & \multicolumn{5}{c}{ Manufacturing output growth (\%) } \\
\hline Country & Mean & Std. & Min. & Max. & Mean & Std. & Min. & Max. & Corr. \\
\hline Benin & 3.68 & 3.14 & -5.02 & 9.48 & 2.90 & 9.27 & -24.05 & 29.55 & 0.38 \\
Burkina & 4.53 & 3.10 & -1.79 & 10.45 & 4.18 & 9.52 & -18.53 & 31.64 & 0.17 \\
Cote d'Ivoire & 2.61 & 4.53 & -11.60 & 12.15 & 2.91 & 7.38 & -12.16 & 18.72 & 0.36 \\
Gambia & 3.64 & 3.37 & -4.42 & 11.68 & 3.75 & 6.04 & -18.41 & 24.78 & -0.08 \\
Ghana & 3.54 & 4.63 & -13.27 & 13.14 & 3.62 & 18.38 & -46.03 & 52.78 & 0.34 \\
Mali & 5.08 & 5.83 & -7.66 & 18.47 & 4.98 & 9.16 & -24.10 & 20.95 & 0.23 \\
Niger & 2.25 & 6.34 & -18.69 & 12.64 & 4.79 & 11.78 & -17.43 & 40.29 & 0.32 \\
Nigeria & 3.89 & 6.73 & -11.37 & 29.07 & 2.69 & 6.92 & -14.03 & 19.98 & 0.50 \\
Senegal & 2.88 & 3.40 & -5.74 & 8.54 & 3.41 & 3.77 & -9.42 & 10.84 & 0.60 \\
Sierra Leone & 2.56 & 6.99 & -21.09 & 23.32 & 5.76 & 20.63 & -18.00 & 82.17 & 0.48 \\
Togo & 2.60 & 5.55 & -16.37 & 13.96 & 3.03 & 14.78 & -44.23 & 58.52 & 0.45 \\
\hline
\end{tabular}

(b)

\begin{tabular}{ccccccccc}
\hline & \multicolumn{3}{c}{ Manufacturing output (\% GDP) } & \multicolumn{3}{c}{ Agricultural output (\% GDP) } \\
\hline Country & Mean & Std. & Min & Max & Mean & Std. & Min & Max \\
\hline Benin & 18.75 & 7.45 & 11.70 & 32.82 & 31.19 & 4.04 & 23.45 & 37.85 \\
Burkina & 21.83 & 2.71 & 16.22 & 28.08 & 33.16 & 3.36 & 28.22 & 40.20 \\
Cote d'Ivoire & 21.09 & 2.58 & 15.15 & 26.26 & 26.28 & 3.52 & 21.20 & 34.00 \\
Gambia & 13.53 & 0.99 & 10.55 & 14.97 & 30.07 & 7.23 & 18.96 & 41.90 \\
Ghana & 21.12 & 6.27 & 6.46 & 28.93 & 44.63 & 0.96 & 22.39 & 65.04 \\
Mali & 18.36 & 5.11 & 9.86 & 28.64 & 43.21 & 9.93 & 33.01 & 66.02 \\
Niger & 16.27 & 3.96 & 6.94 & 22.94 & 42.34 & 9.48 & 20.11 & 65.46 \\
Nigeria & 37.29 & 7.90 & 24.94 & 52.99 & 33.03 & 6.53 & 20.23 & 48.56 \\
Senegal & 21.72 & 2.66 & 16.38 & 25.46 & 18.96 & 2.78 & 13.77 & 24.86 \\
Sierra Leone & 20.14 & 9.47 & 6.79 & 41.01 & 44.81 & 9.36 & 29.60 & 61.96 \\
Togo & 20.58 & 3.32 & 15.53 & 33.13 & 34.27 & 4.82 & 24.08 & 44.14 \\
\hline
\end{tabular}

Note: Std. denotes standard deviation. Corr. denotes the correlation coefficient between GDP growth and manufacturing output growth.

needs to be done by ECOWAS member countries to promote manufacturing sector.

\section{Empirical Results}

As a first step of our empirical analysis, we test for the order of integration of the two series by means of the PP test of Phillips and Perron [15] and the KPSS test of Kwiatkowski et al. [16]. These tests have been performed under the models 
with constant and trend for the level series and with constant for series in first difference. This step is necessary because the bounds test requires the dependent variable to be integrated of order one (I (1)) and the explanatory variables to be I (0) or I (1). The results displayed in Table 2 suggest that the variables are non-stationary in their level but become stationary after taking the first difference. Therefore, $\log$ (GDP) and log (MAN) are I (1) processes. This implies the possibility of long-run relationships among them.

The results of the ARDL bounds test are displayed in Table 3. From this Table we see that there is a long-run relationship between manufacturing output and GDP in nine countries. This implies that the two variables do not move to far away from each other in the long-run. On the other hand, there is a long-run relationship between non-manufacturing and manufacturing output in ten countries.

Table 4 presents the estimations of Kaldor's first law equation. As can be seen, manufacturing growth has a positive impact on the overall economic performance in eight ECOWAS member countries, namely: Benin, Cote d'Ivoire, Ghana, Niger, Nigeria, Senegal, Sierra Leone and Togo. The growth impact of manufacturing is higher in Nigeria and Senegal compared to the rest of the ECOWAS countries. Manufacturing output growth rate of one percentage point induces a 0.64 percentage point and 0.54 percentage point increase in GDP growth in Nigeria and Senegal, respectively. A one percentage point increase in manufacturing growth induces around a 0.20 percentage point increase in GDP growth in Cote d'Ivoire, Niger and Togo. The results from the model with non-manufacturing output growth as the dependent variable show that the non-manufacturing output growth is positively related to the growth of manufacturing output in Nigeria and Senegal. This finding reinforces the leading role

Table 2. Results of unit root tests.

\begin{tabular}{ccccccccc}
\hline \multirow{2}{*}{ Country } & \multicolumn{9}{c}{ PP test } & \multicolumn{5}{c}{ KPSS test } \\
\cline { 2 - 8 } & GDP & MAN & $\Delta$ GDP & $\Delta$ MAN & GDP & MAN & $\Delta$ GDP & $\Delta$ MAN \\
\hline Benin & -2.50 & -2.47 & $-6.85^{*}$ & $-7.50^{*}$ & $0.19^{*}$ & $0.16^{*}$ & 0.34 & 0.06 \\
Burkina & -1.35 & -2.44 & $-7.31^{*}$ & $-10.57^{*}$ & $0.21^{*}$ & $0.21^{*}$ & $0.58^{*}$ & $0.46^{*}$ \\
Cote d'Ivoire & -2.82 & -3.02 & $-4.31^{*}$ & $-7.64^{*}$ & 0.08 & $0.18^{*}$ & 0.15 & 0.28 \\
Gambia & -2.55 & -2.08 & $-7.02^{*}$ & $-5.80^{*}$ & $0.15^{*}$ & 0.12 & 0.11 & 0.20 \\
Ghana & -0.63 & -2.11 & $-4.22^{*}$ & $-4.99^{*}$ & $0.21^{*}$ & 0.11 & $0.66^{*}$ & 0.19 \\
Mali & -0.10 & -2.33 & $-6.64^{*}$ & $-6.97^{*}$ & $0.20^{*}$ & $0.21^{*}$ & $0.56^{*}$ & 0.44 \\
Niger & -1.14 & -1.97 & $-6.03^{*}$ & $-5.42^{*}$ & $0.20^{*}$ & 0.10 & 0.42 & 0.13 \\
Nigeria & -2.58 & $-3.76^{*}$ & $-4.36^{*}$ & $-5.31^{*}$ & $0.19^{*}$ & 0.11 & $0.60^{*}$ & 0.19 \\
Senegal & -1.69 & -2.90 & $-8.31^{*}$ & $-10.05^{*}$ & $0.20^{*}$ & $0.18^{*}$ & 0.39 & 0.07 \\
Sierra Leone & 0.35 & -0.51 & $-5.83^{*}$ & $-4.22^{*}$ & $0.15^{*}$ & 0.13 & 0.37 & 0.35 \\
Togo & -2.84 & -3.02 & $-6.72^{*}$ & $-7.59^{*}$ & 0.09 & 0.12 & 0.05 & 0.17 \\
\hline
\end{tabular}

Note: ${ }^{*}$ denotes the rejection of the null hypothesis at the $5 \%$ level. 
Table 3. Results of bounds test for cointegration.

\begin{tabular}{ccccccc}
\hline \multirow{2}{*}{ Country } & \multicolumn{3}{c}{$\begin{array}{c}\text { Model 1: GDP and } \\
\text { manufacturing output }\end{array}$} & \multicolumn{2}{c}{$\begin{array}{c}\text { Model 2: Non-manufacturing output } \\
\text { and manufacturing output }\end{array}$} \\
\cline { 2 - 7 } & $\mathrm{F}_{\mathrm{GDP}}$ & $\mathrm{F}_{\mathrm{MAN}}$ & Cointegration? & $\mathrm{F}_{\mathrm{NMAN}}$ & $\mathrm{F}_{\text {MAN }}$ & Cointegration? \\
\hline Benin & $5.35^{*}$ & $5.48^{*}$ & Yes & $4.86^{* *}$ & $6.77^{*}$ & Yes \\
Burkina & 2.62 & $11.82^{*}$ & Yes & 1.90 & $8.91^{*}$ & Yes \\
Cote d'Ivoire & 3.20 & $5.91^{*}$ & Yes & 3.29 & 3.18 & No \\
Gambia & 2.80 & $10.39^{*}$ & Yes & 2.64 & $8.50^{*}$ & Yes \\
Ghana & $6.24^{*}$ & 2.03 & Yes & 4.73 & $8.40^{*}$ & Yes \\
Mali & $10.63^{*}$ & 2.21 & Yes & $10.12^{*}$ & 3.33 & Yes \\
Niger & $6.56^{*}$ & $5.88^{*}$ & Yes & $6.75^{*}$ & $6.03^{*}$ & Yes \\
Nigeria & $10.46^{*}$ & $7.20^{*}$ & Yes & $9.80^{*}$ & $5.33^{*}$ & Yes \\
Senegal & 3.93 & 3.29 & No & 2.43 & $6.23^{*}$ & Yes \\
Sierra Leone & 3.92 & 4.00 & No & 3.67 & $6.23^{*}$ & Yes \\
Togo & 2.97 & $5.23^{* *}$ & Yes & $5.57^{*}$ & 3.22 & Yes \\
\hline
\end{tabular}

Note: GDP is real GDP, MAN is real manufacturing output, NMAN is real non-manufacturing output. * denotes the rejection of the null hypothesis at the $5 \%$ level.

Table 4. Kaldor's first law equation.

\begin{tabular}{cccccccccc}
\hline & \multicolumn{3}{c}{ Dependent variable: GDP growth } & \multicolumn{3}{c}{$\begin{array}{c}\text { Dependent variable: } \\
\text { non-manufacturing growth }\end{array}$} \\
\cline { 2 - 9 } Country & \multicolumn{2}{c}{$\Delta$ MAN $_{\mathrm{t}}$} & \multicolumn{2}{c}{ ECM $_{\mathrm{t}-1}$} & \multicolumn{2}{c}{$\Delta \mathrm{MAN}_{\mathrm{t}}$} & \multicolumn{2}{c}{ ECM $_{\mathrm{t}-1}$} \\
\cline { 2 - 9 } Benin & Coef. & t.stat. & Coef. & t.stat. & Coef. & t.stat. & Coef. & $t$. stat. \\
Burkina & $0.08^{* *}$ & 1.65 & $-0.27^{*}$ & -3.24 & $-0.28^{*}$ & -3.97 & $-0.30^{*}$ & -3.43 \\
Cote d'Ivoire & $0.19^{* *}$ & 1.82 & -0.01 & -0.18 & 0.01 & 0.16 & - & - \\
Gambia & -0.02 & -0.20 & 0.08 & 1.13 & -0.17 & -1.59 & 0.07 & 0.97 \\
Ghana & $0.07^{*}$ & 2.29 & $-0.07^{*}$ & -4.52 & $-0.14^{*}$ & -3.56 & $-0.03^{*}$ & -2.77 \\
Mali & 0.11 & 1.19 & $-0.22^{*}$ & -4.21 & -0.09 & -0.77 & $-0.20^{*}$ & -4.15 \\
Niger & $0.20^{*}$ & 2.33 & 0.05 & 0.87 & 0.01 & 0.06 & $-0.09^{* *}$ & -1.71 \\
Nigeria & $0.64^{*}$ & 4.29 & $-0.16^{*}$ & -4.07 & $0.41^{* *}$ & 1.71 & $-0.17^{*}$ & -4.06 \\
Senegal & $0.54^{*}$ & 4.90 & - & - & $0.61^{*}$ & 4.12 & $0.44^{*}$ & 2.37 \\
Sierra Leone & $0.16^{*}$ & 3.60 & - & - & 0.06 & 0.98 & -0.00 & -0.01 \\
Togo & $0.21^{*}$ & 3.83 & $0.10^{* *}$ & 1.90 & 0.04 & 0.63 & $-0.38^{*}$ & -2.79 \\
\hline
\end{tabular}

Notes: MAN is real manufacturing output. The asterisks * and ${ }^{*}$ denote statistical significance at the $5 \%$ and $10 \%$ levels, respectively.

of manufacturing sector. In these two countries, indeed, manufacturing sector is a driving force of economic growth both by its own expansion and by the induced output growth in agriculture and service sectors. Theoretically, the positive impact of manufacturing growth on the overall economic growth is ex- 
plained by transfer of labor from low productivity sectors to the industrial sector. If this is empirically true, the results for the countries under study are not surprising, since most African countries exhibit high levels of employment in informal and agricultural sectors. In such a context, there is scope for transferring labor to manufacturing when this sector grows without impeding the growth of non-manufacturing sector.

The results of the Granger-causality tests are presented in Table 5. The point estimates of the error correction terms show that manufacturing output Granger-causes GDP in the long run in Ghana, Mali and Nigeria, while the reverse causality holds in Burkina Faso, Cote d'Ivoire, Gambia, Niger and Togo. A long-run two-way causal relationship between manufacturing output and GDP exists in Benin. According to this result, GDP influences manufacturing output and manufacturing in turn influences GDP. With respect to the short-run causality, Table 5 suggests a unidirectional causality flowing from manufacturing output growth to GDP growth in Cote d'Ivoire, Niger and Sierra Leone. In Benin, manufacturing is both a cause and a consequence of economic growth. Overall, the causality analysis suggests that manufacturing causes economic growth in Benin, Cote d'Ivoire, Ghana, Mali, Niger, Nigeria and Sierra Leone. The results displayed in Table 6 indicate that manufacturing growth also causes non-manufacturing growth in these countries. The fact that the growth rate of manufacturing output causes the overall economic growth supports Kaldor's first growth law.

\section{Conclusion}

This paper investigated the relation between manufacturing output growth and

Table 5. Results of granger causality tests with GDP.

\begin{tabular}{ccccc}
\hline & \multicolumn{2}{c}{ Short-run causality } & Long-run causality ECT $\mathrm{E}_{\mathrm{t}-1}=0$ \\
\cline { 2 - 4 } Country & MAN does not cause & GDP does not cause & GDP & MAN \\
\cline { 2 - 4 } Benin & $11.05^{*}(0.026)$ & $15.93^{\star}(0.003)$ & $-0.36^{*}(-3.18)$ & $-1.08^{*}(-3.61)$ \\
Burkina & $1.47(0.224)$ & $0.17(0.676)$ & $-0.09(-1.26)$ & $-0.65^{*}(-3.37)$ \\
Cote d'Ivoire & $20.03^{*}(0.000)$ & $4.26(0.371)$ & $0.03(0.47)$ & $-0.28^{*}(-2.05)$ \\
Gambia & $0.30(0.583)$ & $0.40(0.524)$ & $0.09(1.30)$ & $-0.49^{*}(-4.65)$ \\
Ghana & $1.95(0.162)$ & $0.97(0.324)$ & $-0.06^{*}(-3.21)$ & $0.02(0.22)$ \\
Mali & $0.35(0.554)$ & $0.05(0.813)$ & $-0.23^{*}(-3.77)$ & $-0.03(-0.31)$ \\
Niger & $30.70^{*}(0.000)$ & $3.62(0.605)$ & $-0.07(-1.58)$ & $-0.37^{*}(-3.21)$ \\
Nigeria & $1.21(0.270)$ & $0.52(0.46)$ & $-0.11^{* *}(-1.85)$ & $0.09(1.51)$ \\
Senegal & $0.42(0.515)$ & $0.99(0.319)$ & - & - \\
Sierra Leone & $13.81^{*}(0.003)$ & $3.87(0.275)$ & - & - \\
Togo & $0.11(0.738)$ & $1.293(0.255)$ & $0.01(0.29)$ & $-0.45^{*}(-2.89)$ \\
\hline
\end{tabular}

Note: Statistics for Short-run causality are Chi-square statistics with $p$-values in parentheses. Statistics for long-run causality are coefficients on $\mathrm{ECT}_{\mathrm{t}-1}$ with t-statistics in brackets. The asterisks ${ }^{*}$ and ${ }^{*}$ denote statistical significance at the $5 \%$ and $10 \%$ levels, respectively. 
Table 6. Results of granger causality tests with non-manufacturing output.

\begin{tabular}{ccccc}
\hline \multirow{2}{*}{ Country } & \multicolumn{2}{c}{ Short-run causality } & Long-run causality $\mathrm{ECT}_{\mathrm{t}-1}=0$ \\
\cline { 2 - 5 } & $\begin{array}{c}\text { MAN does not cause } \\
\text { NMAN }\end{array}$ & $\begin{array}{c}\text { NMAN does not } \\
\text { cause MAN }\end{array}$ & NMAN & MAN \\
\hline Benin & $0.35(0.551)$ & $1.518(0.217)$ & $-0.21^{* *}(-1.97)$ & $-0.26(-1.27)$ \\
Burkina & $0.55(0.457)$ & $0.06(0.791)$ & $0.02(0.29)$ & $-0.45^{*}(-3.33)$ \\
Cote d'Ivoire & $16.69^{*}(0.002)$ & $12.97^{\star}(0.011)$ & - & - \\
Gambia & $1.83(0.398)$ & $3.50(0.173)$ & $0.09(0.911)$ & $-0.53^{*}(-4.61)$ \\
Ghana & $4.52^{*}(0.033)$ & $0.01(0.901)$ & $-0.000(-0.027)$ & $-0.10^{\star}(-2.04)$ \\
Mali & $0.001(0.937)$ & $0.05(0.807)$ & $-0.21^{\star}(-3.72)$ & $-0.03(-0.33)$ \\
Niger & $33.22^{\star}(0.000)$ & $2.76(0.428)$ & $-0.24^{\star}(-4.64)$ & $-0.07(-0.48)$ \\
Nigeria & $14.03^{*}(0.000)$ & $0.57(0.749)$ & $-0.76^{*}(-3.57)$ & $-0.04(-0.23)$ \\
Senegal & $0.66(0.415)$ & $0.21(0.640)$ & $0.19(0.82)$ & $-0.47^{\star}(-2.19)$ \\
Sierra Leone & $8.63^{*}(0.034)$ & $3.18(0.363)$ & $-0.00(-0.26)$ & $-0.01^{* *}(-1.98)$ \\
Togo & $0.19(0.662)$ & $0.33(0.532)$ & $-0.49^{*}(-3.14)$ & $-0.13(-0.28)$ \\
\hline
\end{tabular}

Note: Statistics for Short-run causality are Chi-square statistics with $p$-values in parentheses. Statistics for long-run causality are coefficients onECT $\mathrm{T}_{\mathrm{t}-1}$ with $t$-statistics in brackets. The asterisks ${ }^{*}$ and ${ }^{* *}$ denote statistical significance at the $5 \%$ and $10 \%$ levels, respectively.

economic growth in ECOWAS member countries from the perspective of Kaldor's first growth law. We examine the validity of this law using cointegration and causality tests. The results suggest that the growth of GDP in most ECOWAS countries is in a significant way positively related to the growth of the manufacturing sector. This result provides support for Kaldor's first growth law. The future economic growth of ECOWAS countries depends on the performance of the industrial sector. Therefore structural transformation in favour of industrial production activities would help to accelerate economic growth in ECOWAS countries. This remains the biggest challenge for African countries which calls for more research.

\section{References}

[1] Verdoorn, P.J. (1949) Fattori che regolano losviluppo della produttività del lavoro. L'Industria, 1, 3-10.

[2] Kaldor, N. (1966) Causes of the Slow Rate of Economic Growth of the United Kingdom. Cambridge University Press, Cambridge.

[3] Bairam, E. (1991) Economic Growth and Kaldor's Law: The Case of Turkey, 1925-78. Applied Economics, 23, 1277-1280. https://doi.org/10.1080/00036849100000048

[4] Atesoglu, H.S. (1993) Manufacturing and Economic Growth in the United States. Applied Economics, 25, 67-69. https://doi.org/10.1080/00036849300000114

[5] Hansen, J.D. and Zhang, J. (1996) A Kaldorian Approach to Regional Economic Growth in China. Applied Economics, 28, 679-685. https://doi.org/10.1080/000368496328425

[6] Necmi, S. (1999) Kaldor's Growth Analysis Revised. Applied Economics, 31, 
653-660. https://doi.org/10.1080/000368499324093

[7] Mc Causland, W.D. and Theodossiou, I. (2012) Is Manufacturing Still the Engine of Growth? Journal of Post Keynesian Economics, 5, 79-92. https://doi.org/10.2753/PKE0160-3477350105

[8] Güçlü, M. (2013) Manufacturing and Regional Economic Growth in Turkey: A Spatial Econometric View of Kaldor's Laws. European Planning Studies, 21, 854-866. https://doi.org/10.1080/09654313.2012.722929

[9] Mercan, M., Kizilkaya, O. and Okde, B. (2015) Are the Kaldor's Laws Valid? Panel Data Analysis under Cross-Section Dependency for NIC Countries. Procedia Economics and Finance, 23, 140-145. https://doi.org/10.1016/S2212-5671(15)00399-8

[10] Szirmai, A. and Verspagen, B. (2015) Manufacturing and Economic Growth in Developing Countries, 1950-2005. Structural Change and Economic Dynamics, 34, 46-59. https://doi.org/10.1016/j.strueco.2015.06.002

[11] Marconi, N., Reis, C.F. and Araújo, E.C. (2016) Manufacturing and Economic Development: The Actuality of Kaldor's First and Second Laws. Structural Change and Economic Dynamics, 37, 75-89. https://doi.org/10.1016/j.strueco.2015.12.002

[12] Kaldor, N. (1967) Strategic Factors in Economic Development. New York State School of Industrial and Labor Relations, Cornell University, Ithaca.

[13] Engle, R.F. and Granger, C.W.J. (1987) Cointegration and Error Correction: Representation, Estimation, and Testing. Econometrica, 55, 251-276.

https://doi.org/10.2307/1913236

[14] Pesaran, H., Shin, Y. and Smith, R.J. (2001) Bounds Testing Approaches to the Analysis of Level Relationships. Journal of Applied Econometrics, 16, 289-326. https://doi.org/10.1002/jae.616

[15] Phillips, P.C.B. and Perron, P. (1988) Testing for a Unit Root in a Time Series Regression. Biometrika, 75, 335-346. https://doi.org/10.1093/biomet/75.2.335

[16] Kwiatkowski, D., Phillips, P.C.B., Schmidt, P. and Shin, Y. (1992) Testing the Null Hypothesis of Stationarity against the Alternative of a Unit Root. Journal of Econometrics, 54, 159-178. https://doi.org/10.1016/0304-4076(92)90104-Y 